\title{
Notes on Norms and Usage of Finite/Non-Finite Predication in Written English
}

\begin{abstract}
English reference grammars mention finite dependent clauses as coexisting with non-finite clauses in the norm of the language. Since finite clauses can express the same syntactic functions as non-finite clauses, the choice of clause normally depends on the speaker's/writer's preference. This paper compares the treatment of finite/non-finite predication in some grammar reference books and presents the results of long-term diachronic research into syntactic functions of finite/ non-finite clauses in academic English and the language of newspapers. The findings indicate that current users of the language seem to employ non-finite forms more frequently now than a hundred years ago. This trend is generally overlooked in the English normative grammars.
\end{abstract}

Key words

Academic English; newspaper language; normative grammar; finite/non-finite predication; syntactic functions of finite/non-finite clauses

\section{Introduction}

This paper presents the results of long-term diachronic research focusing on the use of finite/non-finite predication and changes in syntactic functions of finite/ non-finite clauses in written English. The research originally started with the analysis of academic texts from the fields of psychology and economics, later also sociology. The motivation was to analyse academic texts written a hundred years ago and towards the end of the $20^{\text {th }}$ century or the beginning of $21^{\text {st }}$ century with regard to the development of sentence complexity. As a by-product it was revealed that current academic texts in comparison with the texts written a hun- 
dred years ago display a greater tendency towards a non-finite mode of expression. Texts were then added representing newspaper language taken from The Guardian, The New York Times and Daily Mirror. Since it was rather difficult to find a diachronic study that would aim at the development of finite/non-finite predication and change in syntactic functions of finite/non-finite clauses in written English, the findings of each following study were mainly contextualised with the previous ones (Malá 2009, 2010, 2011, 2012). The main goal was always to ascertain which findings are more universally valid and which are registerdependent only. One of the findings that spans across these two registers is that current users of the language seem to employ non-finite forms more frequently now than a hundred years ago. The first part of the present paper will thus focus on the treatment of finite/non-finite clauses in the normative grammars and some less comprehensive grammar books. The second part will discuss the findings of the above-mentioned long-term diachronic research.

\section{Grammar reference books}

Grammar reference books contain rules for what is considered correct or appropriate usage in the norm of English. Moreover, besides rules, these books often describe tendencies in usage which language users may accept as prescriptivism and then utilize in their own usage. When dealing with defining relative clauses with the relative pronoun in the object position after a personal antecedent (e.g. People I visit), Quirk et al. (1985: 1251) state that "whom here would seem pedantic to many people, while who as object in relative clauses is informal and tends to be regarded as incorrect". That is why "that (and particularly zero) is frequently used...". Another example could be the selection of an anaphoric pronoun which refers to indefinite pronouns denoting humans without specification of sex (e.g. everybody, someone). Huddleston et al. (2002: 492) indicate that when we use $h e$, it is not considered politically correct because it "represents one of the most obvious and central cases of sexism in language". They add that he or she "has long been used as a means of avoiding the sexist bias of he", but may be "regarded as somewhat clumsy. [...] The use of they with a singular antecedent goes back to Middle English, and in spite of criticism since the earliest prescriptive grammars it has continued to be very common in informal style" (Huddleston et al 2002: 493). "However, it is not considered acceptable by some native speakers" (Alexander 1988: 87). Such comments are valuable because they help potential users of the language avoid choosing a formal or pedantic alternative in informal situations as well as avoid using politically incorrect expressions when it is inappropriate. With reference to finite/non-finite predication several grammar reference books and other sources were analysed. They are exhibited in Table 1. The main aim was to detect whether the commentaries of these books reflect what was indicated by the research, namely that in written English the usage of nonfinite clauses is becoming more and more prominent. 
Table 1. Grammar reference books and other sources analysed

\begin{tabular}{|l|l|}
\hline Quirk et al. 1985 & A Comprehensive Grammar of the English Language \\
\hline Biber et al. 1999 & Longman Grammar of Spoken and Written English \\
\hline Biber et al. 2002 & Longman Student Grammar of Spoken and Written English \\
\hline Huddleston et al. 2002 & The Cambridge Grammar of the English Language \\
\hline Alexander 1988 & Longman English Grammar \\
\hline Parrot 2000 & Grammar for English Language Teachers \\
\hline Eastwood 1994 & Oxford Guide to English Grammar \\
\hline Carter and McCarthy 2006 & Cambridge Grammar of English \\
\hline Leech and Svartvik 2002 & A Communicative Grammar of English \\
\hline Jespersen 1940 & A Modern English Grammar on Historical Principles \\
\hline
\end{tabular}

All grammar reference books deal with finite and non-finite clauses. Some slightly differ from each other in terminology and categorization, but basically they discuss all the main functions of finite and non-finite clauses. As for the three major and most authoritative descriptive comprehensive grammar reference books available, namely Quirk et al. (1985), Biber et al. (1999) and Huddleston et al. (2002), all of them describe finite and non-finite clauses and their functions in detail. With reference to non-finite clauses, besides descriptive comments Quirk et al. and Huddleston et al. provide some remarks assessing these structures, though rarely. Non-finite clauses are "valuable as a means of syntactic compression" (Quirk et al. 1985: 995). "Non-finite clauses tend to be significantly less explicit than finite clauses..." (Huddleston et al. 2002: 1211). However, any comments contrasting finite/non-finite clauses are practically non-existent. Rather, different structures are analysed semantically and selection restriction issues are thoughtfully considered. Thus when Huddleston et al. (2002: 1253) deal with non-finite infinitival clauses and finite nominal that clauses after adjectives, if the two alternatives are used interchangeably (e.g. It was necessary for him to walk to school. It was necessary that he walk to school.), it is not indicated whether any of them would prevail. Comments are provided if there is a difference in meaning between a finite and non-finite structure. It was possible for him to walk to school reflects deontic modality, the ability to walk, while It was possible that he walked to school indicates epistemic modality, meaning maybe. Some explanations are also available when the selection restriction influencing the choice of a finite/ non-finite clause is imposed by lexical factors. Thus adjectives concerned with truth or likelihood take finite clauses (e.g. It was obvious that he was lying), while adjectives concerned with ease or difficulty of doing something generally take non-finite clauses (e.g. It was easy for me to sympathise with her.).

Biber et al. (1999) - the third of the largest comprehensive grammar reference books - differ from the other two in that their research is based on the analysis of corpora of 4 registers (academic English, newspaper language, fiction, conversation). Commentaries refer to usage across registers as well as to usage in individual registers. Since the frequencies of occurrence are normalised per mil- 
lion words, the tables and figures are mutually comparable and exhibit clearly which structure is more frequent in which category. Nevertheless, with reference to different functions of finite/non-finite clauses the growing importance of non-finite clauses does not become obvious because the perspective of the grammar reference book is synchronic. Moreover, finite clauses are usually taken as a whole, while non-finite clauses are taken separately. Thus finite postmodification by relative clauses on one hand is contrasted with -ed,-ing and to- clauses expressing non-finite postmodification taken separately. The order of different kinds of postmodification according to the frequency of occurrence is relative clauses, -ed, -ing and to- clauses with finite relative clauses highly prevailing over each kind of non-finite clauses (Biber et al. 1999: 606). Finite/non-finite clauses functioning as adverbials are treated in a similar way. All semantic relationships of finite adverbial clauses are taken as a whole and are opposed to -ed, -ing and to- clauses functioning as adverbials taken separately. It is stated that "In all four registers finite clauses are by far the most common type of circumstance adverbial clause" (826). However, if finite clauses expressing a certain function were taken as a whole and were contrasted with non-finite clauses expressing the same function also taken as a whole, the difference demonstrating the prevalence of finite clauses would not be so sharp.

Less comprehensive grammar books provide some more specific comments more frequently than big grammar reference books. They sometimes indicate that there are two alternative ways (finite and non-finite) of expressing the same communicative intent and offer notes evaluating them. In comparison with finite clauses non-finite clauses are "shorter and neater" (Eastwood 1994: 155), "more economical and avoid repetition" (Leech and Svartvik 2002: 203), but also more formal than finite clauses (Eastwood 1994: 172, Carter and McCarthy 2006: 774, Leech and Svartvik 2002: 203). Sometimes the comments are not unequivocal. "Participle constructions are generally more typical of formal style than of informal, though they can easily occur in both" (Alexander 1988: 30).

When two competing alternatives express the same, some remarks indicating which structure is preferable in which context are valuable. Thus when Biber et al. (2002: 341) discuss a non-finite to- clause with subject-to-subject raising and a finite extraposed that- clause as two alternative forms of expressing the same (e.g. It seems that Andy knows everything. Andy seems to know everything.), they make it clear that non-finite to-clauses are much more frequent in all four registers. The reason is often the division of communicative dynamism in a sentence. The given information appears at the beginning, the new information towards the end.

Parrot, while considering teaching implications, emphasizes that using nonfinite clauses is of utmost importance. In his opinion teachers should help learners "develop and use a mental checklist of functions these clauses frequently have". It is essential for learners not only "to recognise and understand non-finite clauses, but also use them" because they help us express our ideas "more succinctly" (Parrot 2000: 361). 
In Jespersen, the grammar book with a diachronic perspective, we can find notes referring to the origin of different non-finite structures, e.g. the perfect infinitive developed in the Middle English period (Jespersen 1940: 88), the perfect participle "did not come into existence till the $16^{\text {th }}$ century" (94). Such remarks reveal clearly that non-finite forms emerged much later than finite forms. There are comments comparing finite/non-finite forms and suggesting that they can be used interchangeably. "The infinitival nexus-construction in many respects equals a that-clause, and one construction may be substituted for another without the sense being altered" (e.g. They firmly believed him to be innocent. They firmly believed that he was innocent.) (Jespersen 1940: 297). There are even comments assessing the selection restrictions connected with the choice of finite/non-finite forms. "There are, however, some restrictions to the use of the shorter and generally more handy infinitive construction. It can never be placed before the verb..." (e.g. Him to be innocent they firmly believed is not possible while That he was innocent they firmly believed is possible.) (297). Nonetheless, Jespersen does not provide any commentary indicating that some non-finite forms are used more often than finite ones.

The comments found mainly in the less comprehensive grammar books list many features of non-finite clauses. Non-finite structures are shorter, neater, more handy, more economical, more formal than finite structures. By using them we avoid repetition and express our ideas more succinctly. On the whole, however, neither comprehensive nor less comprehensive grammar books provide straightforward unequivocal comments speaking in favour of non-finite clauses.

\section{The use of finite/non-finite clauses from a diachronic perspective}

Unlike grammar reference books, notes suggesting a growing tendency in English to use non-finite forms can be found in research articles and some other literature, even though such claims are again not too frequent. Members of the Prague Linguistic Circle (Mathesius 1961, Vachek 1955) indicated that the use of nonfinite verbal forms or condensers, mainly infinitives, gerunds, participles, is more prominent in analytic languages - e.g. English - than in synthetic languages such as Czech. Vachek proposed a hypothesis about the increase in the use of non-finite forms during the historical development of English within English itself. The hypothesis was confirmed by Hladký (1961), who reported on two translations of identical texts from the Bible, one made in the $17^{\text {th }}$ century, the other in the Modern English period. The diachronic perspective revealed that during the historical development the ratio of finite to non-finite verbal forms changed more strongly in favour of non-finite verbal forms because in the modern translation of the text from the Bible there were significantly more cases of condensers than in the old translation. Some other researchers also noticed that non-finite forms became "more functionally prominent, and correspondingly more frequent in discourse" even though, unfortunately, there is little research into these issues (Mair and 
Leech 2006: 329). Furthermore, there are comments referring to the normative tradition in the Old English period and its change in the direction of non-finite forms with time. "In Old English, with very few exceptions, finite complement clauses were the norm. From around the thirteenth century, the infinitival variants emerged and started spreading (Leech et al. 2009: 183) ... in the seventeenth century gerund emerged and started spreading" (185). Such notes in literature suggesting a growing tendency to a non-finite mode of expression, when viewed diachronically, are in harmony with the findings of the research discussed below.

\section{Material and method of analysis in exploratory studies into academic English and newspaper language}

This part of the paper combines the results of three small-scale descriptive exploratory studies with a diachronic perspective that analyse academic English and three small-scale studies that analyse newspaper language (See Table 2). The aim was to detect changes in the syntactic functions of finite and non-finite clauses which occurred over a hundred-year time span that would be common to both registers. Each study analysed parts of two texts, one published towards the end of the $19^{\text {th }}$ century or the beginning of the $20^{\text {th }}$ century, the other towards the end of the $20^{\text {th }}$ century or the beginning of the $21^{\text {st }}$ century. Regarding the selection of texts, an effort was made to choose texts from the same field which focus on the same or similar topics. As for the academic texts, two are from clinical psychology and describe research on hypnosis, two academic articles are from economics and focus on Britain's fiscal policy and two are book extracts focusing on how to do sociological research. Newspaper language is represented by two texts from The Guardian that report on conferences. Then there are two texts from The New York Times and International Herald Tribune (the global edition of The New York Times) dealing with the Presidential Election in the USA and finally there are also two texts from Daily Mirror that concentrate on the Royal Family. From each text 100 consecutive sentences were chosen as units of analysis. Every explicitly expressed finite and non-finite predication which occurred in the sentences was categorised. The research is based mainly on the theoretical framework of Quirk et al. (1985) and Biber et al. (1999). Table 2 shows that with the exception of the modern texts from International Herald Tribune and Daily Mirror, modern texts consisted of fewer clauses. The text from International Herald Tribune was the only text whose number of words was higher than that of the older text. 
Table 2. The number of clauses and words in 100 sentences of the 6 academic texts and 6 newspaper texts

\begin{tabular}{|l|c|c|c|}
\hline & No. of sentences & No. of clauses & No. of words \\
\hline Psychology -1907 & 100 & 436 & 3,582 \\
\hline Psychology -2005 & 100 & 286 & 2,057 \\
\hline Economics -1904 & 100 & 438 & 4,233 \\
\hline Economics - 1997 & 100 & 307 & 2,629 \\
\hline Sociology -1888 & 100 & 358 & 3,230 \\
\hline Sociology -1995 & 100 & 265 & 2,133 \\
\hline Guardian 1907 & 100 & 392 & 3,323 \\
\hline Guardian 2010 & 100 & 304 & 1,933 \\
\hline New York Times 1902 & 100 & 280 & 2,227 \\
\hline International Herald Tribune 2012 & 100 & 365 & 2,392 \\
\hline Daily Mirror 1903 & 100 & 268 & 2,546 \\
\hline Daily Mirror 2012 & 100 & 282 & 1,976 \\
\hline & 1,200 & 3,981 & 32,261 \\
\hline
\end{tabular}

\subsection{Categories of explicitly expressed finite and non-finite predications}

Explicitly expressed finite and non-finite predications are categorised as main clauses and finite and non-finite subordinate clauses. Subordinate clauses are further divided into 4 syntactic categories according to the functions they perform in sentences. There are clauses occupying a noun phrase slot, clauses occupying an adverbial element slot, clauses contributing to the complexity of noun phrases in the form of pre- and postmodification and comment clauses. In the examples below, parts of sentences illustrating individual categories are presented in italics.

Clauses occupying a noun phrase slot as subject, object, complement

Sentences (1) and (2) show clauses substituting for clause elements that are normally expressed by noun phrases. Sentence (1) illustrates a nominal that clause performing the function of direct object. In (2) there is a to- clause functioning as direct object.

(1) The Queen looked fantastic... and her eyes showed that she was excited. (Daily Mirror 2012)

(2) As he walked in, members tried to grasp his hand, and the ex-President smiled. (The New York Times 1902)

\section{Clauses occupying an adverbial element slot}

Examples (3) and (4) show finite and non-finite clauses substituting for adverbials. In (3) there is an adverbial clause of time, in (4) the infinitive of purpose. 
(3) ... the second Christmas... will be as quietly and as enjoyably spent as they were when their Majesties were Prince and Princess of Wales. (Daily Mirror 1903)

(4) She... said she would fight to defeat the president's agenda of socialism. (Int. Herald Tribune 2012)

Clauses contributing to the complexity of noun phrases in the form of pre-and postmodification

To keep to the criterion of explicitly expressed predication, examples of -ing and -ed participles used as premodification which are formed by adding a suffix to a verb base were counted as non-finite clauses. In example (5) neglected infrastructure can be easily changed into infrastructure that is neglected.

(5) Western capitalism survives, but limping, wounded, carrying a heavy load of debt, inequality, demography, neglected infrastructure. (The Guardian 2010)

Example (6) illustrates postmodification by a finite clause (a defining relative clause), in (7) there is postmodification by an -ed participle.

(6) Lay people have the opportunity to acquire beliefs and opinions about hypnosis and hypnotherapy, that included hypnotic enhancement of imagination and recollection. (psychology 2005)

(7) It is not necessary to lay exclusive stress upon an argument advanced in the present controversy. (economics 1904)

\section{Comment clauses}

Example (8) demonstrates a comment clause which has the form of a main clause. In (9) the comment clause in non-finite.

(8) Here visual representation is the rule, and it will, I think, be found... (psychology 1907)

(9) But she similarly failed, to begin with, in the hypnotic state. (psychology 1907)

\subsection{Results and discussion}

Table 3 shows main, finite subordinate and non-finite clauses in all 6 pairs of texts. Next to the absolute numbers of clauses in the modern texts there are arrows pointing upwards or downwards and next to them percentages by which the main, finite subordinate and non-finite clauses in/decreased in the modern texts. As regards finite subordinate clauses and non-finite clauses, it can be seen that 
when the absolute numbers of clauses decrease in the modern texts (psychology 2005, economics 1997, sociology 1995, The Guardian 2010) and the decreases are converted to percentages, finite clauses decrease more than non-finite clauses (e.g. in economics 1997 finite subordinate clauses decreased by $50 \%$, non-finite clauses by $26 \%$.). On the other hand, when the absolute numbers of clauses increase in the modern texts (Inter. Herald Tribune 2012, Daily Mirror 2012), again converted to percentages, finite clauses increase less than non-finite clauses (e.g. in Daily Mirror 2012 finite clauses increased by 3\%, non-finite clauses by 57\%.). Thus the results of the diachronic research in all the six studies are consistent. It seems that in written English, when viewed diachronically, there is an increased tendency to the non-finite expression of subordinate clauses and to the reduction of finite clauses. This was interpreted as a tendency towards a non-finite mode of expression in written English (Malá 2011, 2012). If we adopt the synchronic perspective and compare the absolute numbers of finite subordinate clauses with the absolute numbers of non-finite clauses in individual sets, in six cases there are more finite clauses than non-finite clauses (psychology 1907, psychology 2005, economics 1904, The New York Times 1902, International Herald Tribune 2012 and Daily Mirror 1903), in one case the number of finite and non-finite clauses is the same (in The Guardian 1907 there are 143 finite subordinate clauses and 143 non-finite subordinate clauses) and in five cases there are more non-finite clauses than finite clauses (economics 1997, sociology 1888, sociology 1995, The Guardian 2010 and Daily Mirror 2012). In other words, if the perspective is synchronic, there are still more finite clauses than non-finite ones. The tendency towards a non-finite mode of expression becomes apparent when the perspective is diachronic.

Table 3. Main, finite, non-finite clauses in the 6 academic texts and 6 newspaper texts (Abs. ${ }^{*}$ - absolute numbers of clauses)

\begin{tabular}{|l|c|c|c|c|c|c|}
\hline \multirow{2}{*}{} & \multicolumn{2}{|c|}{ Main clauses } & \multicolumn{2}{c|}{ Finite sub. clauses } & \multicolumn{2}{c|}{ Non-finite clauses } \\
\cline { 2 - 7 } & Abs. ${ }^{*}$ & $\%$ & Abs. & $\%$ & Abs. & $\%$ \\
\hline Psychology - 1907 & 138 & & 182 & & 116 & \\
\hline Psychology - 2005 & 115 & $\downarrow 17 \%$ & 94 & $\downarrow 48 \%$ & 77 & $\downarrow 34 \%$ \\
\hline Economics - 1904 & 126 & & 181 & & 131 & \\
\hline Economics - 1997 & 119 & $\downarrow 6 \%$ & 91 & $\downarrow 50 \%$ & 97 & $\downarrow 26 \%$ \\
\hline Sociology - 1888 & 124 & & 110 & & 124 & \\
\hline Sociology-1995 & 113 & $\downarrow 9 \%$ & 66 & $\downarrow 40 \%$ & 86 & $\downarrow 31 \%$ \\
\hline Guardian 1907 & 106 & & 143 & & 143 & \\
\hline Guardian 2010 & 122 & $\uparrow 15 \%$ & 84 & $\downarrow 41 \%$ & 98 & $\downarrow 31.5 \%$ \\
\hline New York Times 1902 & 131 & & 81 & & 68 & \\
\hline Int. H. Tribune 2012 & 119 & $\downarrow 9 \%$ & 125 & $\uparrow 54 \%$ & 121 & $\uparrow 78 \%$ \\
\hline Daily Mirror 1903 & 150 & & 60 & & 58 & \\
\hline Daily Mirror 2012 & 129 & $\downarrow 14 \%$ & 62 & $\uparrow 3 \%$ & 91 & $\uparrow 57 \%$ \\
\hline
\end{tabular}


The development of individual categories (finite/non-finite clauses substituting for clause elements normally expressed by noun phrases, clauses used as adverbials, clauses developing noun phrases in the form of pre- and postmodification and comment clauses) can be seen in Tables 4-7. The representation of individual categories has sometimes in/decreased dramatically in the hundred-year time span.

Table 4. Percentages of finite clauses according to functions in academic texts

\begin{tabular}{|l|c|c|c|c|c|c|}
\hline & \multicolumn{2}{|c|}{$\begin{array}{c}\text { Finite clauses - } \\
\text { psychology }\end{array}$} & \multicolumn{2}{c|}{$\begin{array}{c}\text { Finite clauses - } \\
\text { economics }\end{array}$} & \multicolumn{2}{c|}{$\begin{array}{c}\text { Finite clauses - } \\
\text { sociology }\end{array}$} \\
\hline & 1907 & 2005 & 1904 & 1997 & 1888 & 1995 \\
\hline Postmodification & 36 & 38 & 57 & 29 & 40 & 35 \\
\hline Adverbial element & 33 & 13 & 25.5 & 37 & 26 & 38 \\
\hline Noun phrase slot & 26 & 47 & 15.5 & 34 & 25 & 24 \\
\hline Comment clauses & 5 & - & 2 & - & 9 & 3 \\
\hline Premodification & - & 2 & - & - & - & - \\
\hline Total & 100 & 100 & 100 & 100 & 100 & 100 \\
\hline
\end{tabular}

Table 5. Percentages of finite clauses according to functions in newspaper texts

\begin{tabular}{|l|c|c|c|c|c|c|}
\hline & \multicolumn{2}{|c|}{$\begin{array}{c}\text { Finite clauses - } \\
\text { Guardian }\end{array}$} & \multicolumn{2}{c|}{$\begin{array}{c}\text { Finite clauses - } \\
\text { New York Times }\end{array}$} & \multicolumn{2}{c|}{$\begin{array}{c}\text { Finite clauses - } \\
\text { Daily Mirror }\end{array}$} \\
\hline & 1907 & 2010 & 1902 & 2012 & 1903 & 2012 \\
\hline Postmodification & 40 & 37 & 38 & 34 & 60 & 19 \\
\hline Adverbial element & 13 & 19 & 27 & 20 & 27 & 42 \\
\hline Noun phrase slot & 43 & 40 & 25 & 32 & 10 & 34 \\
\hline Comment clauses & 4 & 4 & 10 & 14 & 3 & 5 \\
\hline Premodification & - & - & - & - & - & - \\
\hline Total & 100 & 100 & 100 & 100 & 100 & 100 \\
\hline
\end{tabular}

Table 6. Percentages of non-finite clauses according to functions in academic texts

\begin{tabular}{|l|c|c|c|c|c|c|}
\hline & \multicolumn{2}{|c|}{$\begin{array}{c}\text { Non-finite cl. - } \\
\text { psychology }\end{array}$} & \multicolumn{2}{c|}{$\begin{array}{c}\text { Non-finite cl. - } \\
\text { economics }\end{array}$} & \multicolumn{2}{c|}{$\begin{array}{c}\text { Non-finite cl. - } \\
\text { sociology }\end{array}$} \\
\hline & 1907 & 2005 & 1904 & 1997 & 1888 & 1995 \\
\hline Postmodification & 45 & 32 & 46.5 & 30 & 38 & 31 \\
\hline Adverbial element & 14 & 25 & 14 & 31 & 12 & 22 \\
\hline Noun phrase slot & 26 & 26 & 24.5 & 27 & 23 & 30 \\
\hline Comment clauses & 2 & - & - & - & 2 & - \\
\hline Premodification & 13 & 17 & 15 & 12 & 25 & 17 \\
\hline Total & 100 & 100 & 100 & 100 & 100 & 100 \\
\hline
\end{tabular}


Table 7. Percentages of non-finite clauses according to functions in newspaper texts

\begin{tabular}{|l|c|c|c|c|c|c|}
\hline & \multicolumn{2}{|c|}{$\begin{array}{c}\text { Non-finite cl. - } \\
\text { Guardian }\end{array}$} & \multicolumn{2}{c|}{$\begin{array}{c}\text { Non-finite cl. - } \\
\text { Int. H. Tribune }\end{array}$} & \multicolumn{2}{c|}{$\begin{array}{c}\text { Non-finite cl. - } \\
\text { Daily Mirror }\end{array}$} \\
\hline & 1907 & 2010 & 1902 & 2012 & 1903 & 2012 \\
\hline Postmodification & 45 & 26 & 31 & 28 & 29 & 26 \\
\hline Adverbial element & 16 & 19 & 28 & 20 & 31 & 31 \\
\hline Noun phrase slot & 29 & 35 & 28 & 39 & 28 & 26 \\
\hline Comment clauses & - & - & - & - & - & - \\
\hline Premodification & 10 & 20 & 13 & 13 & 12 & 17 \\
\hline Total & 100 & 100 & 100 & 100 & 100 & 100 \\
\hline
\end{tabular}

The changes that are more universally valid, which means valid both for academic texts and newspaper language, are as follows. Postmodification by finite and nonfinite clauses is in most cases the most frequently used category in the old texts. In some cases it is by far the most frequently used category (e.g. postmodification by finite clauses in economics 1904 represents 57\%, in Daily Mirror 1903 even $60 \%$. Postmodification by non-finite clauses in economics 1904 represents 46.5\% of non-finite clauses, in The Guardian 1907 as well as psychology 1907 it is $45 \%$.). With only one exception (finite clauses in psychology 2005 where it slightly increased) this category was reduced in the modern texts. In Malá (2012) it was illustrated how the reduction of finite and non-finite postmodification contributes to straightforwardness of expression. When it is used, it interrupts the flow of the texts by giving details about noun phrases. Reading a text with many postmodifications puts considerable stress on the concentration of the reader.

When we look at the percentages of finite and non-finite clauses used instead of clause elements normally expressed by noun phrases (subject, object, complement) and adverbials, we can see that these two categories often increase in the modern texts, in some cases rather substantially. (E.g. in Daily Mirror finite clauses substituting for noun phrases increase from $10 \%$ to $34 \%$, those used as adverbials from $27 \%$ to $42 \%$. In the text from economics the percentage of nonfinite clauses substituting for adverbials increases from 14\% to 31\%. In International Herald Tribune the percentage of non-finite clauses used instead of clause elements normally expressed by noun phrases rose from $28 \%$ to $39 \%$.) Clauses used instead of noun phrases and adverbials contribute significantly to the development of argument because they express thoughts, stances and different kinds of circumstances. As for premodification, it is a very economical means of expression because just one word can substitute for a whole clause. As the findings show, the use of premodification increases mainly in newspaper language. Finally, comment clauses do not play a significant role.

For the purpose of the main topic of the present paper the most important change that can be referred to as more universally valid, meaning that it occurred both in academic texts and newspaper language, includes an increasing tendency 
to a non-finite mode of expression. The others - the reduction of postmodification by finite/non-finite clauses and increase in finite/non-finite clauses used instead of noun phrases and as adverbials - are important too, but they lie beyond the scope of the present paper.

\section{Conclusion}

English normative grammars deal with finite/non-finite clauses in considerable detail. With reference to the choice between finite/non-finite clauses they carefully consider selection restriction issues imposed by lexical factors, the division of communicative dynamism in a sentence, differences in meaning between finite/ non-finite structures and other points. When both finite and non-finite structures can be used interchangeably, the English normative tradition does not generally indicate priority of usage. Both types of clauses simply co-exist in the norm of the language. In comprehensive grammar reference books (Quirk et al. and Huddleston et al.) the comments comparing finite/non-finite structures are rather rare. Since the third comprehensive grammar reference book - Biber et al. - in some cases contrasts finite clauses as a whole with individual types of non-finite clauses expressing the same function, finite clauses seem to prevail more than they actually do. In less comprehensive grammar books we can find remarks evaluating non-finite structures as neater, more handy, more economical, but no straightforward comments speaking in favour of finite or non-finite clauses.

The diachronic research into academic English and newspaper language revealed that current users of the language seem to employ non-finite forms more frequently now than a hundred years ago. When we compared portions of 100 sentences of texts from these two periods and the modern texts contained fewer subordinate clauses than the old texts, then, consistently, the findings showed that finite clauses decreased more than non-finite clauses. When, on the other hand, the modern texts contained more subordinate clauses than the old texts, finite clauses increased less than non-finite clauses. This fact was interpreted as a tendency towards a non-finite mode of expression in written English. This tendency becomes apparent only when the perspective is diachronic. Since the grammar reference books usually deal with the language from a synchronic perspective, they do not provide comments referring to tendencies in usage over time. From a synchronic perspective it is certainly true that finite subordinate clauses are still used more than non-finite clauses.

If further research proves that the above-mentioned claims are valid, the findings would have some important pedagogical implications. The findings of the research may also trigger further questions. If finite/non-finite forms can be used interchangeably and current users of English use non-finite forms in writing more now than a hundred years ago, then how do writers make decisions in favour of non-finite forms? Are their decisions intentional or incidental? Are the writers aware of them? By using non-finite forms we achieve certain syntactic economy 
because we avoid repeating what is clear from the surrounding context. In current academic English and newspaper language there is certainly a trend towards greater brevity. Unlike the writers of 100 years ago, modern writers are often given instructions on the maximum length of their articles. Using non-finite forms instead of finite ones certainly contributes to syntactic compression of texts, usually making them shorter, but also, as mentioned above, significantly less explicit. These are only some of the issues that could be investigated by further research.

\section{Acknowledgement}

This article was supported by Grant SGS 5846/2012 of the Technical University of Liberec.

\section{References}

Alexander, Louis G. (1988) Longman English Grammar. London: Longman.

Biber, Douglas, Stig Johansson, Geoffrey Leech, Susan Conrad and Edward Finegan (1999) Longman Grammar of Spoken and Written English. London: Longman.

Biber, Douglas, Susan Conrad and Geoffrey Leech (2002) Longman Student Grammar of Spoken and Written English. Harlow: Pearson Education.

Carter, Ronald and Michael McCarthy (2006) Cambridge Grammar of English. Cambridge: Cambridge University Press.

Eastwood, John (1994) Oxford Guide to English Grammar. Oxford: Oxford University Press

Hladký, Josef (1961) "Remarks on complex condensation phenomena in some English and Czech contexts". Brno Studies in English 3, 105-118.

Huddleston, Rodney and Geoffrey K. Pullum (2002) The Cambridge Grammar of the English Language. Cambridge: Cambridge University Press.

Jespersen, Otto (1940) A Modern English Grammar on Historical Principles. Part V. George Allen and Unwin. Ejnar Munksgaard

Leech, Geoffrey, Marianne Hundt, Christian Mair and Nicholas Smith (2009) Change in Contemporary English. A Grammatical Study. Cambridge: Cambridge University Press.

Leech, Geoffrey and Jan Svartvik (2002) A Communicative Grammar of English. Longman: Pearson Education.

Mair, Christian and Geoffrey Leech (2006) "Current changes in English syntax". In: Aarts, Bas and April MacMahon (eds.) The Handbook of English Linguistics. Oxford. Blackwell, 318-342.

Malá, Marcela (2009) "The development of sentence complexity in academic prose written in English: Psychology 1907-2005”. In: Kuzniak, Marek and Božena Rozwadowska (eds.) PASE Papers 2008. University of Wroclaw, 79-88.

Malá, Marcela (2010) "Syntactic functions of finite and non-finite clauses in academic English". Discourse and Interaction 3 (1), 73-85.

Malá, Marcela (2011) Sentence Complexity in Academic Written English: A Syntactic Study with a Diachronic Perspective (1904-2005). LAP: Lambert Academic Publishing.

Malá, Marcela (2012) "Change in Syntactic Functions of Finite/Non-Finite Clauses in Newspaper Language: Similarities and Differences between Academic Prose and Newspaper Language". BAS Journal. 243-252. 
Mathesius, Vilém (1961) Obsahový rozbor současné angličtiny na základě obecně lingvistickém. A functional Analysis of Present Day English on a General Linguistic Basis. Praha: Nakladatelství československé akademie věd.

Parrot, Martin (2000) Grammar for English Language Teachers. Cambridge: Cambridge University Press.

Quirk, Randolph., Sidney Greenbaum, Geoffrey Leech and Jan Svartvik (1985) A Comprehensive Grammar of the English Language. London: Longman.

Vachek, Josef (1955) "Some Thoughts on the So-called Complex Condensation in Modern English”. Sborník praci filosofické fakulty brněnské university. A3, 63-77.

\section{Sources}

Mitchell, W. T. (1907) “The appreciation of time by somnabules". Reprinted unaltered in Mitchell, W. Thomas (1922) Medical psychology and psychical research. London: Methuen \& Co. LTD, 44-55.

Furnham, A. \& E. Lee (2005) "Lay beliefs about, and attitude towards hypnosis and hypnotherapy". Counseling and clinical psychology journal. 2 (3), 90-96.

Price, L.L. (1904) "Economic theory and fiscal policy". The Economic Journal. 14 (55), 377-387.

Pain, N., M. Weale \& G. Young. (1997) "Britain's Fiscal Problems”. The Economic Journal. 107 (443), 1142-1151.

Webb B. (1888) "Personal Observation and Statistical Enquiry. The Art of Note-Taking. Printed in My Apprenticeship - 2". 1938. Pelican Books. 464-469, 472-475.

Schaefer, R.T. and R.P. Lamm (1995) Sociology. New York. Mc Graw-Hill. 39-45.

The Guardian (1907) April 22. Colonial Conference. Retrieved from http://www.archive.guardian. co.uk. $15^{\text {th }}$ January 2011.

The Guardian (2010) November 2. We've been conned.

The New York Times (1902) June 20. Cleveland and Hill to the democracy. Retrieved from http:// www.nytimes.com/ref/membercenter/nytarchive.html, $10^{\text {th }}$ February 2012.

International Herald Tribune. (The global edition of The New York Times) (2012) January 10. Romney puts hopes on New Hampshire., Money pouring in as Republicans battle., January 5. Republican unity proves elusive.

Daily Mirror (1903) December 22. How the King and Queen spend Christmas. Retrieved from Daily Mirror Digital Archive. http://www.journalism.co.uk/news/daily- mirror-archives. 14 ${ }^{\text {th }}$ April 2012.

Daily Mirror (2012) June 4, 3, 2. Diamond Jubilee Pageant. Retrieved from http://www.mirror. co.uk. $2^{\text {nd }}$ June, $3^{\text {rd }}$ June, $4^{\text {th }}$ June 2012

Marcela Malá is a Senior Lecturer at the Technical University of Liberec, Czech Republic. She has published papers on English linguistics and TEFL. Her current research interests include syntax, text linguistics and teaching English grammar. Her book Sentence Complexity in Academic Written English; A Syntactic Study with a Diachronic Perspective was published in 2011.

Address: PhDr. Marcela Malá, M.A., Ph.D., English Department, Faculty of Science, Humanities and Education, Technical University of Liberec, Voroněžská 13, 46001 Liberec I, Czech Republic. [e-mail:marcela.mala@tul.cz] 